\section{ASPECTOS DOS “BOG BODIES” E DO “CULTO \\ DA CABEÇA DECEPADA” NA BRETANHA \\ PRÉ-HISTÓRICA E ROMANA}

RESUMO: Religião e práticas mortuárias caminharam de mãos dadas na Bretanha da Idade do Ferro e Romana (Britannia). Tanto as fontes clássicas quanto a cultura material indicam que os bretôes desenvolveram algum tipo de culto à água, o que poderia ajudar a explicar a deposição dos corpos das turfeiras (bog bodies). Alguns desses corpos mostram sinais de ritos sacrificiais, como estrangulamento e decapitação. Outros locais de enterramento na Bretanha contêm corpos decapitados, cujas cabeças estão depositadas em vários locais e posições no túmulo. Crânios decepados são, ainda, encontrados em poços, fossos e rios. Pode haver em questão um "culto da cabeça decepada", de alguma conexão com cultos da água, sacrifícios, até mesmo, execuções. Tais práticas obscuras detectadas na Idade do Ferro continuaram, embora de forma duvidosa, na Britannia. Procuraremos ressaltar os principais aspectos de tais costumes e as implicações para o estudo das representações da morte entre os bretôes, e da atenção da mídia para com o assunto.

PALAVRAS-CHAVE: Bog Bodies, Culto da Cabeça Decepada, Britannia, Sacrifício, Religião Romana.

ASPECTS OF THE "BOG BODIES" AND THE "SEVERED HEAD CULT” IN IRON AGE AND ROMAN BRITAIN

ABSTRACT: Religion and mortuary practices walked hand-in-hand in Iron Age and Roman Britain. The classical sources and material culture both indicate the Britons developed some sort of water-cult and this may help to explain the deposition of the so called bog bodies. Some of these bodies show signs of sacrifice rites such as strangulation or decapitation.

\footnotetext{
* Professor Adjunto do Departamento de História da Universidade Federal de PernambucolBrasil; Pesquisador Associado do Laboratório de Arqueologia Romana Provincial do MAE-USP. E-mail: tdhm@ uol.com.br.

** Jornalista, escritor e discente do curso de História pela Universidade Estácio de Sá - RJ\Brasil. E-mail: lisztrangel@ hotmail.com
} 
Other burial sites in Britain include decapitated bodies, whose heads are found in various places and positions within the grave. Severed skulls can also be found in wells, shafts and rivers. There can be a "severed head cult" in question with some connection with water-cults, and sacrifices or even, executions. These obscure practices detected in Iron Age continued, albeit in arguable fashion, well into Roman Britain. We aim to highlight the main aspects of such customs and the implications for the study of death representations among the Britons and of the media attention drawn to the subject.

KEYWORDS: Bog Bodies, Severed Head Cult, Roman Britain, Sacrifice, Roman Religion.

\section{INTRODUÇÃO}

Este estudo almeja cotejar os principais aspectos relacionados às formas como os bretôes representaram a morte por meio da deposição de seus mortos em locais tidos como sagrados, e da presença de mutilaçôes nos cadáveres, como o caso das cabeças decepadas. Entendemos aqui a prática mortuária como, também, uma maneira de representar a morte, no limite, não separando, portanto, práxis de representação. A história da Bretanha, imediatamente antes dos romanos, até 43 d.C. - quando lá chegaram as legiōes do imperador Cláudio a fim de torná-la uma província, a Britannia - foi classificada por arqueólogos e historiadores como Pré-História, estando os povos nativos na Idade do Ferro Tardia (Late Iron Age) (SALWAY, 1989, p. 1). Os rituais funerários dos bretóes envolviam inumações e cremações. Os sepultamentos da elite (barrows) encimados por colinas (mounds) são comuns na era anterior à Idade do Ferro, mas continuam em voga até ao menos o período da Idade do Ferro Tardia (SALWAY, 1984, p. 670). A Idade do Ferro foi marcada, ainda, pelas construçōes dos fortes nas colinas (Hill forts, ou oppida, para os romanos), e por sua elaborada metalurgia em bronze, na fabricação de armaduras e escudos artísticos, de forma geral chamada de "arte celta". O termo é controverso e ainda há muito mais dúvidas do que respostas a respeito do período nessa região da Europa. A partir dessa época, um sem número de artefatos de metal é encontrado em forma de depósito deliberado, vo- 
tivo, imagina-se, em regiōes próximas a corpos d'água, o que leva à interpretação de que a água teria sido considerada um elemento místico, de aproximação com as divindades dos bretôes (JOY, 2009, p. 21). Nestes locais, também, encontram-se restos humanos. Os sepultamentos em outros locais, úmidos ou não, poderiam apresentar uma característica marcante: as cabeças decepadas, removidas do túmulo, ou colocadas em variadas posiçōes no seu interior, geralmente entre os pés dos cadáveres. Teriam essas cabeças sido cortadas ritualisticamente após a morte, ou seriam indícios de sacrifícios humanos ou até mesmo execuções? A prática se manteve até o fim do período romano, ao que tudo indica. Que significados teriam tais formas de representar a morte entre os bretôes? Serão esses aspectos os nossos principais campos de análise ao longo deste estudo. Optamos aqui pelo uso do termo "prática mor-

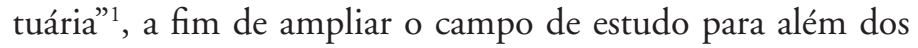
corpos colocados apenas em necrópoles.

Escrever sobre as práticas mortuárias nas ilhas britânicas deve nos remeter às pesquisas do mesmo tema em regiōes próximas, no continente. Os bretôes parecem ter compartilhado de inúmeras práticas mortuárias com as sociedades do norte da Gália e de parte da Germânia, por exemplo. Os contatos entre os habitantes, por meio do Canal da Mancha, existiram de forma regular já bem antes da chegada dos romanos e assim teriam continuado ao longo dos quatro séculos de ocupação. Contudo, não se trata de eliminar as idiossincrasias dos ilhéus, que podem ter desenvolvido rituais e práticas próprios, com diferenciações mesmo entre as tribos. $\mathrm{O}$ tema das transferências culturais é complexo e não pretendemos nos aprofundar neste debate no momento, focando-nos em aspectos gerais dos bretōes, sem a preocupação em buscar as origens e paralelos fora da aérea geográfica proposta. Neste estudo, procuramos utilizar o termo "Bretanha" ao nos referirmos ao território onde habitavam os bretôes durante a chamada Idade do Ferro, referente à atual ilha da Grã-Bretanha. Ao designarmos o mesmo local, enquanto província romana, utilizaremos o termo Britannia.

Com a perspectiva de analisarmos como a morte poderia ter sido representada de maneira multifacetada no tratamento dado aos corpos dos mortos da Bretanha antes e depois do período provincial, nossos objetivos e métodos
1. Sobre a nomenclatura, ver Ribeiro, 2007, p. 19. 
pretendem-se múltiplos, e segmentados. O primeiro, mais geral, será apresentar um panorama não exaustivo e circunscrito das práticas mortuárias levadas a cabo na Bretanha, da Idade do Ferro, e na Britannia, quando província romana, com destaque para os primeiros três séculos da era cristã. Para além do recorte cronológico, que não almeja tratar do período tido como de "cristianização" da ilha, a circunscrição recai, primordialmente, na escolha de dois aspectos apenas, ainda que fulcrais, entre uma miríade de representações mortuárias dos bretôes: o sacrifício humano e o "culto da cabeça decepada". Num segundo momento, procuraremos elencar como os textos clássicos nos apresentam as práticas religiosas dos bretôes antes da invasão romana de 43 d.C.. Aqui, o destaque será a conexão entre os cultos druídicos do continente e da Bretanha, assim como suas características percebidas como "naturalistas", ao adotar como loci de ritualização da morte as florestas e os corpos d'água da ilha. Apresentaremos um estudo de caso, o do Homem de Lindow, a fim de refletirmos sobre a deposição de corpos, mutilados ou não, em turfeiras, os famosos bog bodies, e suas implicações nas discussões acerca da prática ritualística do sacrifício humano entre os bretôes da Idade do Ferro e durante os primeiros séculos de presença romana na ilha. Em seguida, apresentaremos exemplos, e refletiremos a respeito da prática de decepar ou mutilar os corpos inumados nas necrópoles da Idade do Ferro e do período romano inicial, seus possíveis significados e a possível configuração de um "culto da cabeça decepada" entre os bretôes. Procuraremos observar se teria havido mudanças significativas entre os dois períodos estudados, também. Por fim, analisaremos, pondo em tela a tênue linha que separava rito de execução penal, suas implicações no mundo atual, em especial, o papel da mídia na divulgação dos temas tratados aqui.

Uma explicação: os casos de deposição de restos humanos sem marcas ritualísticas visíveis, geralmente associados a atos criminosos, de execução, exibição, ou destruição física punitiva serão também abordados na medida em que chamar a atenção para seu caráter ambíguo parece fomentar interesse por parte dos pesquisadores e pode levar a reflexôes a respeito do uso da violência no mundo romano e seus significados para o nosso presente. 
A religiāo para os romanos, politeísta e antropomórfica, tinha um papel fundamental, talvez mesmo, o de elemento aglutinador do estado (Políbio. Histórias, VI, 56). A observância dos rituais, cujas origens estavam envoltas em grandes mistificações, não era um mero detalhe, como lembrava Plínio, o Velho, ao mencionar, inclusive, a prática do sacrifício humano (Plínio, o Velho. NH, XXVIII, 10-12). Antes, a vida em sociedade dependia da crença na sacralidade de praticamente todas as ações políticas e sociais, inclusos aqui as práticas da guerra e os acordos da paz (FUNARI, 1994, p. 15-6). Pode-se, contudo, ressaltar que a crença no sobrenatural não residia apenas na seara da religiosidade formal, regrada, havia ainda o campo das crenças mais populares, nem sempre sancionadas pelo estado, mas nem por isso menos importante ou popular. Mesmo as camadas mais desprovidas de direitos ou de riquezas, como os escravos, tinham suas práticas religiosas (FUNARI, 1994, p. 17-20).

Para o especialista em religião, Martin Henig (1984), ao fim da República, reinava certo pessimismo e cinismo, fenômeno que se estende ao início do Principado. Sobre a crença no além-túmulo, vamos desde os praticamente descrentes epicuristas Lucrécio e César, passamos pelo otimismo cauteloso de Tácito, em seu encomium para Agrícola (Agr. 46), indo à sublimação da vida eterna em Cícero (que em outros momentos é menos efusivo), em Sommium Scipionis (HENIG, 1984, p. 190). Como exemplo de carpe dien, um sepultamento na Britannia recomenda que se beba o vinho e que se aproveite bem a vida enquanto a sua estrela brilha (RIB I, 292).

Ainda durante a República e boa parte do Principado, a noção de uma existência pós-morte pressupunha um rito de passagem, presente em obras como a Eneida, de Virgílio, ao descrever a visita de Eneias ao mundo subterrâneo, o Tártaro, ao pagar com moedas o barqueiro, Caronte, pela travessia do rio Aqueronte (Virgílio. Eneida, VI; OTTAWAY, 2013, p. 219).

Religião e práticas mortuárias andavam então unidas no mundo romano. Não havia uma forma única de se sepultar alguém naquele mundo. Poderia haver tendências, contudo: num primeiro momento, consumir o corpo na cremação pa- 
recia ser a melhor das opções. Depois, fortaleceram-se o Neoplatonismo, os cultos dionisíacos, os cultos orientais de mistérios, e a inumação ganhou terreno sobre a cremação (HENIG, 1984, p. 190).

A lei romana proibia o enterro nas cidades e mesmo o contato com os mortos era mal visto. Para muitos, no entanto, os mortos deveriam ser lembrados e se livrar da solidão do túmulo ou da morte. Precisavam ser vistos, igualmente, e por isso os sepultamentos nas estradas, perto das cidades (SALWAY, 1984, p. 694; RADFORD, 2013a, p. 56). Como argumenta Joan Alcock (1980, p. 60f), o morto, num ambiente estranho, teria então de se sentir em casa. Libações de vinho eram feitas à "sombra" divina do morto (dis manibus). Os sacrifícios, de (quase) toda sorte, são pedidos: Virgílio fala que espíritos se levantam com sacrifícios (Eneida, VI, 23663; HENIG, 1984, p. 193). Um desrespeito ao espirito do morto poderia significar sua presença entre os vivos como um fantasma, um ser temido pelos romanos, cuja ira precisava ser aplacada (SALWAY, 1984, p. 696). Plinio, o Jovem conta uma interessante história de fantasma em Atenas (Ep. VII, 27). Somente leprosos e loucos viviam em cemitérios (HENIG, 1984, p. 195-199). Os romanos, à meia noite, faziam rituais de expulsão de fantasmas (lemures), durante a Lemuria (Ovídio. Fasti, V, 419ff).

\section{A RELIGIĀO DOS BRETÔES}

O estudo da religião dos bretôes, antes da chegada romana, é um empreendimento bastante complexo para os pesquisadores. Os bretôes, assim como os germanos (Tácito. Germ., IX), parecem ter dado pouca ou nenhuma importância à criação de templos para seus deuses e deusas. As divindades nativas não ganhavam representação antropomórfica física explícita: nem esculturas, tampouco dedicações escritas que pudessem perdurar por muito tempo (OTTAWAY, 2013, p. 88). Quando da chegada dos romanos, deuses e deusas nativos tiveram seus atributos e nomes muitas vezes mesclados aos das divindades ditas romanas. Só a partir de então, seguindo formas de representação que se aproximavam do estilo clássico, ganharam versão física material e textual (SALWAY, 1984, p. 665-6). Algumas moedas do período da Idade do Ferro, como 
as de prata, dos icênios, traziam representações de animais, como o cavalo (SEALEY, 2004, p. 9-10; OTTAWAY, 2013, p. 287), que poderia estar associado à religião da Bretanha, ainda que o estilo e o meio não deixaram de ser influenciados pela forma clássica e pelo uso do latim nas inscrições (SALWAY, 1984, p. 669), elementos já bem difundidos no continente quando a Britannia se tornou uma província, em 43 d.C..

$\mathrm{O}$ estudo da cultura material bretã não logra esclarecer com detalhes os cultos da Bretanha antes dos romanos, e em algumas ocasiōes, são os estudos realizados na Irlanda ou no País de Galês, de vestígios, por vezes, posteriores ao mundo romano, que são utilizados para referendar as práticas religiosas dos bretōes na Idade do Ferro (GREEN, 1986, p. 14-17). $\mathrm{O}$ risco de tais aproximações é o de pressupormos que os bretôes compartilhavam dos costumes religiosos de seus vizinhos sem que desenvolvessem suas próprias formas de cultuar suas divindades. De fato, a influência dos cultos de outras regióes tidas como celtas, da Gália e proximidades, na religião bretã não pode ser ignorada. Contudo, há mostras de que os bretôes parecem ter cultuado divindades ou desenvolvido práticas religiosas próprias. A deusa Coventina, por exemplo, parece ser de origem local, associada à sacralidade da água, e cultuada em Carrawburgh, no muro de Adriano (SALWAYM, 1984, p. 666). Algumas divindades chegavam por meio dos soldados das legiōes e de suas tropas auxiliares, vindas da Germânia, ou, ainda, de regióes bem distantes da Britannia (RIB I, 1576). Da região leste do Império vieram Ísis, Sol Invictus, introduzidos na Britannia por volta do séc. II d.C, e tornados populares no III d.C., e os mistérios de Elêusis, os cultos de Cibele, mitraismo e cristianismo. As representações de tais divindades são de difícil interpretação e classificação, dadas as mesclas entre si, mas parece claro que é preciso estudar a religiosidade da Bretanha tendo em mente alguma influência do continente, sem descartarmos a idiossincrasia dos cultos locais (SALWAY, 1984, p.668-9).

Os bretões costumavam enterrar sua elite em túmulos depois cobertos de terra até que se formassem colinas (moun$d s$ ) sobre eles, os barrows (ou tumuli, em latim). Talvez fruto da influência da Gália no período da Idade do Ferro denominado La Tène I, ficaram particularmente famosos os tumuli da Culura Arras, de Yorkshire, na Idade do Ferro e no início 
do período romano, onde se podem encontrar túmulos de guerreiros, com armas e carros de guerra enterrados junto aos cadáveres (SALWAY, 1984, p. 10, 670). Se tomarmos como correto o que disse Júlio César e outros romanos escreveram, os celtas acreditavam que seus guerreiros teriam recompensas após a morte em batalha. Isso os deixava mais perigosos. Havia em túmulos de chefes bretóes elementos que faziam referência à comida e bebida, como ânforas de vinho, potes de barro e de vidro, ao estilo do barrow de Welwyn, em Hertfordshire. Certos barrows de período já romano podiam conter moedas para Caronte e para pagamento da passagem pelo rio, outros, mistura de mel e vinho, um famoso aperitivo romano (mulsum) (HENIG, 1984, p. 191-3).

O Homem de Lindow e os SACRifícios de uma "Religião NATURAL"

Das características da religião dos bretôes, que eram também, em alguma medida, compartilhadas em outros locais do Império, inclusive pelos próprios romanos e gregos, merece destaque o culto a céu aberto, sem templos: uma religião "natural". Em destaque, o significado religioso atribuído à água e às florestas. Não se crê mais hoje em dia em um norte da Europa todo coberto por densa vegetação arbórea (SALWAY, 1984, p. 672, contra HENIG, 1984, p. 17), mas consta bastante documentada a importância de arvoredos e clareiras (nemeton, ver etimologia em HENIG, 1984, p. 17-8) nos cultos bretôes durante a Idade do Ferro e no período romano (SALWAY, 1984, p. 672; OTTAWAY, 2013, p. 88). Díon Cássio faz referência à clareira onde Boudica teria sacrificado seus prisioneiros e buscado convencer seu exército a continuar a luta contra os romanos por meio de um vaticínio da deusa Andata/Andraste (epitome, LXII, 7). Rios, lagos, turfeiras (dos famosos bog bodies, comentados adiante), áreas alagadas, poços e nascentes tinham suas divindades próprias, como Sulis Minerva, em Bath, e a deusa bretã Coventina, já citada acima, e eram palco de sacrifícios e de deposição votiva de objetos simples ou de luxo, assim como de restos orgânicos de vítimas (SALWAY, 1984, p. 669-70). Na turfeira de Llyn Cerric Bach, em Anglesey, foi achado um tesouro de peças em ferro vindas da região sul e leste da Inglaterra. Isso pode fazer parte da 
tradição celta de depósito votivo em água (SALWAY, 1984, p. 679-80), e, pode-se traçar algum paralelo com o depósito de grandes tesouros dedicados às divindades na Gália, no fundo de lagos (Estrabão. Geografia, IV, 13; HENIG, 1984, p. 17). Talvez a inserção de objetos em poços, fossos e lagos possa ter alguma conotação sexual de penetração e fertilização da terra (HENIG, 1984, p. 17). Sendo assim, propomos aqui retomar a questão dos sacrifícios realizados em áreas úmidas com um estudo de caso, o do Homem de Lindow (Lindow Man).

Os sacrifícios de animais parecem indicar que o poder dos deuses precisava ser respeitado e temido. Mas talvez não fosse apenas o sangue de animais o derramado, pois, como já mencionado, Plínio, o Vellho, assim como Júlio César, também nos fala dos sacrifícios humanos em certas partes do Império, dando o tom de reprovação enfática, por lei, à prática $(\mathrm{NH}, \mathrm{XXX}, 3)$. O horror ao sacrifício parece ter prevalecido nas mentes romanas, mas a lei não pode evitar por si só que restos humanos fossem usados de forma sorrateira para a obtenção de favores ou para encantaçōes maléficas (Tácito. Ann. II, 69).

No caso da Britannia, a descoberta do corpo de um rapaz perto de Manchester, em Cheshire, na turfeira de Lindow Moss, em 1984, levou os pesquisadores a refletirem com mais vigor sobre os ritos de sacrifícios humanos entre os bretóes, mesmo em período romano, quando a prática seria tida como criminosa. O Homem de Lindow (Lindow Man), como ficou conhecido, pode ter sido morto, aparentemente, em um ritual de sacrifício no século. I d.C. - algo entre o ano 2 e 119 d.C. (JOY, 2009, p. 23), com o uso de um garrote para o estrangulamento, degolação sendo que, ainda conta com uma contusão com fratura cranial, fruto de um golpe dado no momento da morte (OTTAWAY, 2013, p. 89).

Os restos mortais do Homem de Lindow foram achados na turfeira de Lindow Moss, de maneira acidental, durante a coleta da turfa para ser tratada como combustível, fertilizante e biorremediação. $\mathrm{O}$ achado foi analisado pelo arqueólogo Rick Turner, que determinou logo de início que se tratava de um corpo ali depositado há, ao menos mil, anos (JOY, 2009, p. 5).

Os tecidos dérmicos do cadáver estavam bem preservados, assim como todo o seu torso superior, e do rapaz podiam 
2. Para um estudo recente a respeito de bog bodies na Irlanda, ver Kelly (2013). ser visualizadas as feições do rosto, o cabelo, os músculos e a única vestimenta que possuía: uma braçadeira de pele de raposa. No entorno do pescoço, uma corda trançada de tendão animal deixara marcas de estrangulamento, e o crânio apresentava perfuração por trauma. Na dimensão do interesse que a descoberta despertou no público em geral, quando o canal de notícias britânico BBC produziu em 1985 um documentário sobre a limpeza em laboratório dos vestígios do corpo de "Pete Marsh", como a mídia inicialmente chamou o Homem de Lindow, o programa foi visto por mais de dez milhões de espectadores. Ainda hoje, o corpo, em exposição no Museu Britânico, é um dos itens mais visitados do acervo, tornando-o uma "celebridade pré-histórica", nas palavras da curadora de Idade do Ferro do museu, Jody Joy (2009, p. 12).

Contudo, o corpo do Homem de Lindow não foi o único a ser achado no local. Ao menos outros três corpos antigos, em estados diferenciados de preservação, foram encontrados de maneira fortuita durante o trabalho de corte da turfa. Entre tais vestígios, o crânio de uma mulher, desenterrado em 1983, parcialmente preservado, na faixa etária entre trinta e cinquenta anos, ainda com um dos glóbulos oculares e parte do couro cabeludo. Os exames de radiocarbono apontaram para um enterramento do crânio da "Lindow Woman" há quase mil e oitocentos anos (JOY, 2009, p. 17). Outras partes de corpos foram encontradas em Lindow Moss após 1987, inclusive os prováveis membros inferiores do Homem de Lindow (JOY, 2009, p. 20).

A descoberta do Homem de Lindow em Lindow Moss está associada a um grupo de descobertas arqueológicas de restos humanos em pântanos e turfeiras. São áreas úmidas, ou encharcadas, tomadas por material vegetal decomposto, musgo, em especial, que se transforma em turfa, um material tornado inflamável pelo acumulo de metano em sua composição. Substâncias liberadas pelo musgo sphagnum em deterioração, como certos açúcares, transformam aquele ambiente em um curtume, preservando assim os tecidos moles (JOY, 2009, p. 32-3). Os corpos de turfeiras (bog bodies), talvez mais de dois mil deles até agora, têm sido encontrados ao longo dos últimos dois séculos em grande parte da região noroeste da Europa: nas ilhas britânicas, na Holanda, Dinamarca e em partes da Alemanha. ${ }^{2}$ Os corpos podem ter de seis mil a 
pouco mais de uma centena de anos. Geralmente, tratam-se de corpos depositados entre 500 a.C. e 100 d.C... Até o fim do último século, dadas as precárias condições de preservação dos corpos depois de retirados das turfeiras, somente uma pequena porção destes pode ser conservada, e existem até hoje, não mais do que vinte (JOY, 2009, p. 24). No caso das ilhas britânicas, há registros de descobertas de bog bodies a partir do séc. XVII d.C.. Muito das turfeiras desapareceu desde o séc. XIX devido à extração do material para uso industrial, e hoje, o Lindow Moss ocupa somente um décimo de sua extensão de alguns poucos séculos atrás (JOY, 2009, p. 20-1).

Em uma possível associação com o Homem de Lindow, foi descoberta em 1958, em Worsley Moss, a vinte quilômetros de Lindow Moss, a cabeça de um rapaz entre vinte e trinta anos, que havia sido decapitada e apresentava fraturas do crânio. Da mesma forma que com o Homem de Lindow, a cabeça de Worsley Moss tinha ainda um cordão ao redor do que sobrara de seu pescoço. Exames de datação indicam que o Homem de Worsley teria sido morto, de forma ritualística, já no período de ocupação romana, talvez no início do sec. II d.C. (PAIN, 2003, p. 48; JOY, 2009, p. 21). Portanto, não muito distante no tempo da estimativa de data da morte do Homem de Lindow - entre 2 e 119 d.C. (JOY, 2009, p. 23).

A deposição dos bog bodies pode, por sua vez, indicar uma prática ritualística de oferenda às divindades bretãs (JOY, 2009 , p. 23). Com o resultado dos testes de carbono 14 , não se pode ter certeza se o Homem de Lindow foi um habitante da Idade do Ferro ou se fora um romano-bretão. Diante do fato de que os romanos reprimiam os sacrifícios humanos, a interpretação de sua morte pode se abrir para outras possibilidades que não a do sacrifício (JOY, 2009, p. 23). Contudo, seria muito ingênuo imaginarmos que os romanos no noroeste da Britannia, no local da turfeira, no séc. I d.C., tivessem condiçōes efetivas de controlar todo o território a fim de deter o sacrifício do Homem de Lindow, fosse esse o caso.

Do Homem de Lindow, os exames de tomografia computadorizada, de ressonância magnética e de xerorradiografia usados para se estudar as estruturas ósseas e os tecidos moles, como as trabéculas, mostraram ferimentos internos e fragmentos de ossos no interior da cavidade craniana, além da fratura de pescoço. Os exames da clavícula determinaram sua 
idade: algo em torno de vinte e cinco anos. Infelizmente, os dentes estavam muito mal preservados e não puderam ser bem estudados até o momento (JOY, 2009, p. 24-5, 27, 53).

A altura do Homem de Lindow está estimada em aproximadamente $1,68 \mathrm{~m}$, um pouco mais alto do que a média de outros esqueletos masculinos da época, pesava algo em torno de $64 \mathrm{~kg}$, e seu cabelo, negro, que teria sido cortado com tesouras, tendo entre 1 e $9 \mathrm{~cm}$ de cumprimento. Há possíveis indícios de que o Homem de Lindow lixava as unhas, e não há sinais de que tivesse se dedicado a alguma atividade de trabalho manual nos meses que antecederam sua morte (JOY, 2009, p. 27). Teria sido um membro da nobreza? Ou alguém especialmente preparado para o sacrifício?

Seu estomago estava parcialmente preservado e parte dos intestinos, também. Havia comido trigo e cevada, tendo o primeiro sido parte de um alimento assado a mais de $200^{\circ} \mathrm{C}$ (JOY, 2009, p. 29). Em outros bog bodies cujos aparelhos digestivos haviam sido preservados, como nos casos de outros corpos do Lindow Moss (Lindow III), do Old Croghan (Irlanda), do Tollund Man e do Grauballe Man (ambos da Dinamarca), os vestígios das últimas refeiçôes encontradas parecem ser o de um mingau cozido de trigo, castanhas ou de ervas. Pólen de visco foi encontrado em pouca quantidade no estômago do Homem de Lindow, mas não se pode ter certeza se há aqui alguma ligação com o que Plínio, o Velho, falara dessa planta, e das práticas religiosas dos druidas (Plínio, o Velho. NH, XVI, 95; Joy 2009: 30).

O corpo do Homem de Lindow apresenta vários ferimentos que podem ter contribuído para sua morte, mas a ordem em que foram infligidos ou mesmo o verdadeiro grau de severidade não podem ser estabelecidos de forma precisa. Todavia, mais distante de alguma explicação satisfatória, está o motivo para sua morte, ou, ainda, o porquê de tantas laceraçōes que se supõem serem fatais isoladamente. A fratura no topo da cabeça, em forma de "V", pode ter sido causada por um pequeno machado, a partir de um golpe de grande impacto. $\mathrm{O}$ ferimento apresenta sinais de início de cicatrização, indicando que o Homem de Lindow teria sobrevivido por algum tempo, questão de minutos ou de poucas horas, após o desferimento do golpe, ainda que inconsciente. Outras fraturas na região do occipital foram identificadas, mas o estado de decomposição do crânio nessa região não permite es- 
boçar mais detalhes. Ao redor do pescoço, um laço de tendão animal desconhecido, de $1,5 \mathrm{~mm}$ de diâmetro deixou marcas de estrangulamento, inclusive com ruptura da coluna. O lado direito do pescoço conta com outro possível ferimento e parece haver um pequeno corte de $3 \mathrm{~cm}$ na altura da clavícula direita. Pode haver, ainda, uma perfuração do lado direito do peito, mas há pele nessa região está muito deteriorada. Também fraturadas estavam duas costelas, a oitava e a nona, no lado esquerdo posterior (JOY, 2009, p. 30-42).

Como já mencionado, não é possível se ter certeza da ordem em que esses ferimentos foram desfechados. $\mathrm{O}$ antropólogo físico Robert Connolly (1985) acredita que o Homem de Lindow recebeu diversos golpes em sua cabeça até primeiro alcançar a inconsciência e, então, o golpe final, fatal, que lhe quebrou o pescoço. Para Connolly, o laço ao redor do pescoço era um simples adorno, ainda que estivesse muito reteso, $\mathrm{e}$ as marcas de ligadura deixadas seriam resultado do inchaço do corpo após a morte. As pontas do laço estavam muito bem cortadas, indicando um cuidado especial para o artefato, o que parece descartar que tenha sido um mero garrote. Os outros ferimentos do Homem de Lindow podem ser atribuídos à manipulação do corpo após a morte, mesmo o lido com o corpo no momento de sua descoberta na modernidade (JOY, 2009, p. 43-4). Mas, por que tantos golpes na cabeça? Se confirmados, terão ainda de ser contabilizadas as outras lacerações, e, desta maneira, a morte do Homem de Lindow teria sido marcada por grande violência. Seu corpo estava nu, teria sido assaltado? A presença de pólen de visco em seu estômago ligaria sua morte a rituais religiosos, ou seja: teria sido o Homem de Lindow um exemplo de sacrifício humano entre os bretões, ou mesmo romano-bretões? $\mathrm{O}$ visco pode ter sido parte de uma refeição final, que antecedeu seu sacrifício, ao menos assim acredita a pesquisadora de religião da Idade do Ferro, Anne Ross. Para Ross, o Homem de Lindow teria sofrido uma "morte tripla": golpes na cabeça, estrangulamento e degola. Além disso, poderia ter sido afogado também, já que seu corpo foi depositado de bruços n'água. Cada uma de tais "mortes" da vítima teria servido ao sacrifício de uma divindade diferente (JOY, 2009, p. 44-5).

A tese do sacrifício humano encontra guarita na comparação das características do Homem de Lindow com outros bog bodies estudados em distintas áreas da Europa setentrio- 
nal, em especial, com base na ainda influente obra do arqueólogo dinamarquês Peter Vilhelm Glob, The Bog People (1965). Glob ressalta como outros corpos encontrados em turfeiras foram quase sempre vítimas de mortes violentas, degoladas, desnudas, e deliberadamente submergidas nos pântanos, sendo ainda algumas amarradas.

Todavia, a hipótese de que a vida do Homem de Lindow tenha sido tirada em um sacrifício tem de conviver com uma série de questionamentos: teria morrido em período anterior à chegada dos romanos àquela região, por volta dos anos 60 d.C.? Tampouco sabemos se era nativo da ilha, ou mesmo se era considerado ou se identificava como um romano, por exemplo. Tais variantes poderiam mudar em muito a situação em que se deu sua morte. Sendo romano ou estrangeiro, dificilmente seria um voluntário para o sacrifício, por exemplo. Se as pessoas que deram origem aos bog bodies seguiram voluntariamente para o fim ou não, parece ser indefinível, mas a importância que a água tinha para a religiáo da Idade do Ferro no norte da Europa, consideradas as fontes clássicas, poderia desvelar um propósito ritualístico para a presença dos corpos nas turfeiras. Mais uma vez, os corpos d'agua devem ser lembrados como importante meio sagrado, dada sua associação com a fertilidade (OTTAWAY, 2013, p. 90).

Outros corpos foram encontrados próximos do Homem de Lindow, sendo o do Homem de Worsley, a vinte quilómetros do primeiro, de período indubitavelmente romano. Que os romanos tenham proibido o sacrifício humano não significa que a prática não pudesse se dar na clandestinidade, deixando espaço para essa interpretação, mesmo após a chegada das legiōes em 43 d.C.. O esqueleto do Homem de Worsley, como já citado acima, apresenta sinais claros de morte violenta, foi decapitado, e conta com muitas fraturas cranianas e um laço ao redor da área do pescoço. Não parece um acidente que esses corpos tenham sido encontrados tão próximos um do outro. Seus ferimentos, múltiplos e significativos, parecem apontar para um overkill, e, também, indicar que os corpos foram propositadamente colocados de bruços n'agua, longe de assentamentos conhecidos. Pode haver pistas sobre as motivações para suas mortes nessas características, mas, por ora, qualquer consenso parece estar fora de cogitação. O corpo do Homem de Lindow, por outro lado, desperta um grande interesse por parte dos visitantes do Museu 
Britânico, talvez movidos, justamente, pela presente áurea de mistério que cerca as circunstâncias de sua morte.

\section{DRUIDAS E SACRIFÍCIOS HUMANOS}

Naquilo que diz respeito à religião romana, de forma geral, os sacrifícios humanos em rituais religiosos eram tidos como aberrações. Apesar de encontrarmos, por vezes, referências aos sacrifícios humanos, esses seriam momentos de grande exceção, e os romanos tinham por norma não aceitar a prática (SALWAY, 1984, p. 665; 680), que poderia deflagrar campanhas militares contra os infratores, como teria sido o caso da perseguição aos druidas. A respeito desse segmento religioso do norte da Europa, nossas informações são precárias.

Há, na obra de Júlio César (De Bel. Gal. VI, 16), o teste dos limites para a tolerância religiosa romana. Os romanos tendiam a não ver com bons olhos a figura de sacerdotes "profissionais", categoria a qual poderiam anexar os druidas. Além disso, parece que os druidas seriam capazes de mobilizar resistências aos romanos, dando a estes um motivo militar para a perseguição (SALWAY, 1984, p. 676-7). Mas teria havido outra motivação, ainda mais pungente: contrário às normas religiosas romanas, os druidas também presidiriam sacrifícios humanos, quando prisioneiros de guerra e criminosos, ou, na ausência destes, inocentes mesmo, seriam queimados vivos em imagens colossais feitas de vime trançado. Tudo a fim de aplacar a ira dos deuses, e na crença de que só uma vida perdida no sacrifício poderia garantir outra mais valiosa nas batalhas contra os inimigos ou contra as doenças. Tácito (Ann. $\mathrm{XIV}, 30)$ menciona que os druidas estavam praticando sacrifício humano nos arvoredos e nas clareiras de Mona (Anglesey) quando do ataque do governador romano Suetônio Paulino. Os romanos podem ter visto no sacrifício druídico de humanos uma paródia horrenda de seus próprios sacrifícios com animais, assim como mais tarde os cristãos viriam os cultos a Mitras como um travestismo de seu culto (SALWAY, 1984, p. 680-1, 772). O sacrifício humano poderia, ainda, configurar-se uma contravenção à Lex Iulia de ui publica (HENIG, 1984 , p. 206). Os romanos não pareciam se opor aos locais sagrados dos bretóes contudo, pois o arvoredo de Mercúrio 
3. Sobre mortes de criança, em um trabalho ainda inconclusive da arqueóloga Stephanie Papas, ver a reportage, de 26 de janeiro de 2014, sobre infanticídio com desequelíbrio de gênero: http://news. discovery.com/history/ roman-infanticide-didntspare-either-sex-140126. htm. Acessado em 05/03/2014. em Rigonemetos continuou em existência depois da revolta de Boudica, debelada por Suetônio (HENIG, 1984, p. 207).

Para Martin Henig (1984, p. 20), parece haver indícios de que os druidas reconheciam que alguns deuses pediam sacrifício humano, como Esus, Taranis, Teutatis entre outros. Em Ashill, Norfolk, e em Cambridge, foram descobertos fossos religiosos da Idade do Ferro com muitos depósitos votivos, em uso no período dos Flávios. Estavam lá cães e também restos humanos, de bebês, vestidos com pequenos sapatos. Talvez tenham sido vítimas da mortalidade infantil apenas. As crianças no mundo romano não tinham muitos direitos ao nascer. A decisão cabia ao pai. Há corpos de crianças sacrificadas ou que teriam morrido por falta de cuidados em Hambledon Villa e em Springhead. Para Henig, haveria poucas evidências que os sacrifícios de adultos e de crianças continuaram em período romano (HENIG, 1984, p. 23-4). Mas após a escrita de sua obra, em 1984, outros exemplos se revelaram, como veremos adiante. ${ }^{3}$

Entre os achados da região de Bedfordshire, o crânio de uma mulher perto do poço em Odell, poderia indicar que foi vítima de um sacrifício (SALWAY, 1984, p. 691-2). A respeito de sapatos nas inumaçôes, cuja presença é muitas vezes apenas atestada pelos pequenos pregos que sobrevivem ao tempo, trata-se de uma prática ainda pouco compreendida pelos estudiosos. A presença de pregos/tachas para sapatos é uma fonte para interpretações variadas, em especial, quando são as únicas vestimentas encontradas nos enterramentos. Tais pregos são comuns no séc. I d.C. na Bretanha, em Puckeridge (com pares de botas) e no cemitério de Curbridge, em Oxfordshire, este último já bem tardio (séc. III ou IV d.C.). Geralmente, os pregos estão perto dos pés, mas podem ser achados em outros locais, indicando que podiam ser lá colocados apenas para representar os calçados, sem que estes tenham, de fato, sido depositados. Em Dunstable, duas inumaçōes continham botas colocadas sob os joelhos dos cadáveres (SALWAY, 1984, p. 705-6; HENIG, 1984, p. 199-200). Haveria uma indústria para esses pregos funerários apenas? Sapatos para a jornada após a morte?

No cemitério de Curbridge, foram encontrados três esqueletos com suas cabeças entre os pés, cercados de pregos de sapatos (SALWAY, 1984, p. 706). Que faziam as cabeças fora 
de lugar? A prática da decapitação oferece um fértil campo de estudo, ainda que esteja longe de oferecer respostas. Os autores tratam do fenômeno como o "culto da cabeça decepada".

\section{As CABEÇAS DECEPADAS}

As práticas funerárias na Bretanha, antes e durante a presença romana, seguiram determinados padrōes, sem nunca, contudo, terem alcançado a unificação em qualquer das formas que tomaram. Dois grandes procedimentos tiveram lugar: a cremação sem um local específico de depósito, e vários tipos de enterramento: das cinzas, e dos corpos (inumação). A cremação parece ter prevalecido entre os séculos I e II d.C., quando, então, a inumação ganhou terreno. No cemitério de St. Pancras, em Chichester, foram achados duzentos e sessenta enterramentos, sendo apenas nove as inumações. O cemitério é, primordialmente, da era flaviana, embora tenha sido usado até o séc. IV d.C... Em contraste, em um cemitério rural de Hampshire, o Martyr Worthy, com uso do século II ao IV d.C., havia apenas inumaçôes. Em parte, poder-se-ia falar de influência cristã, e da crença na ressurreição do corpo para explicar tal transição. Mas há exceções ao padrão: o grande cemitério em Guilden Morden, em Cambridgeshire, tinha anomalias, como uma bela inumação do séc. I d.C., e uma cremação do final do séc. III. Na verdade, a prática da inumação já estava estabelecida nos cultos pagãos na Bretanha antes da chegada maciça do cristianismo (SALWAY, 1984, p. 693). Apesar de se desenhar alguma coerência nas práticas, como dito, houve variações significativas nos padrōes. Caberia observarmos algumas, tendo em vista diferentes regiōes correspondentes de partes da então província da Britannia, como a de Yorkshire e a de Essex, mais especificamente, a de Colchester, todas na atual Inglaterra. Para fins de nosso estudo das cabeças decepadas, nos concentraremos nas inumaçōes.

$\mathrm{Na}$ região de Yorkshire, pode ser notada uma relevante tradição de inumação nos cemitérios da chamada Cultura Arras, da Idade do Ferro, definida e nomeada a partir da tipologia dos vestígios arqueológicos encontrados nos tumuli (barrows) do leste de Yorkshire, em especial, no de Arras, no início do séc. XIX (OTTAWAY, 2013, p. 36). Nestes enterramentos, o cadáver era quase sempre depositado em posição fetal, ou 
com joelhos semiflexionados, talvez em uma referência ao caráter cíclico da vida. Trata-se de uma prática que persistiria, ainda que bem reduzida, durante todo o período de ocupação romana da região (OTTAWAY, 2013, p. 90; 286). A presença de objetos funerários nos enterramentos Arras não é significativa, sendo reduzida a poucos espelhos de ferro e colares de contas de vidro. Também se encontram sepultamentos de ovelhas e de cabritos adjacentes aos dos humanos (OTTAWAY, 2013, p. 90).

Para além da região da Cultura Arras, não se apresentam muitos enterramentos do período da Idade do Ferro, o que sugere que a maior parte dos mortos não era sepultada (contra SALWAY, 1984, p. 693). Trata-se de uma questão em aberto, pois a cremação ao fim da Idade do Ferro, teria sido também pouco comum na região de Yorkshire, ou bem menos do que o fora mais ao sul ou no centro da Bretanha. Com tão poucos corpos encontrados nas inumaçóes, fato associado a pouca quantidade de vestígios nas cremaçóes em enterramentos, o destino da maioria dos corpos dos mortos de Yorkshire, na Idade do Ferro, constitui um mistério. Aguardam ser descobertos, ou deve ter havido outra forma de disposição dos corpos, talvez a remoção da carne, uma "escarnação", o que exporia os restos aos elementos e a animais necrófagos (OTTAWAY, 2013, p. 91-2).

A partir de 43 d.C, com a invasão do imperador Cláudio, o impacto inicial da presença romana nas práticas funerárias bretãs pode ser um rico campo de investigações. Segundo o arqueólogo Patrick Ottaway (2013, p. 154), aparentemente, a prática do enterramento permaneceu rara, ao menos durante o início da presença romana, com exceção da região da Cultura Arras, onde a inumação em vala rasa foi o meio mais comum de enterramento: os corpos, ainda em posição fetal, ou de joelhos semiflexionados, caso de quatorze corpos inumados no pequeno cemitério de Blealands Nook, escavado no início do séc. XX. A prática dos enterramentos com joelhos flexionados está, contudo, longe de representar a maioria dos casos em período romano, e prevalecem os corpos em posição estendida e supina, com braços ao longo do corpo ou dobrados sobre a cintura (OTTAWAY, 2013: 224; 286). Mesmo em enterramentos do séc. II ou IV d.C. podem ser encontrados alguns poucos corpos com os joelhos flexionados, como o 
de um homem e de uma mulher em Catterick (OTTAWAY, 2013, p. 219; 288-9). O que significaria a manutenção ou a reutilização da prática?

A escassez de enterramentos na região de Yorkshire encontra alguma compensação na cidade de Eboracum (York), um local de grande presença militar. Lá, os enterramentos se deram em cemitérios de larga extensão, fora dos limites da cidade, ao longo das estradas, como era o costume romano. Muitos deles continham objetos de luxo no interior dos túmulos, com grande variedade de prática funerária: cremação e inumação, com prevalência da primeira (OTTAWAY, 2013, p. 219). Em Eboracum, os enterramentos tidos como da elite estão próximos do ponto mais elevado (chamado de The Mount) da estrada principal que ligava a cidade ao sul da província. As principais necrópoles eram as de Burton Stone Lane, Clifton Fields, Heworth, Fishergate e a mais bem escavada, Trentholme Drive, com cinquenta e três cremaçōes. Muitos destes locais continuaram a receber enterramentos por séculos (OTTAWAY, 2013, p. 220-1).

Um grupo de esqueletos, desprovidos de caixôes de qualquer tipo, achados próximos ao The Mount, em Driffield Terrace, merece destaque por conter cinquenta e três homens adultos em meio a somente sete não adultos. Entre os adultos, ao menos trinta estavam decapitados, tendo sido os crânios depositados entre os pés, as pernas ou na região da pélvis (OTTAWAY, 2013, p. 224).

Uma relevante questão que se coloca aos especialistas é a capacidade de discernir quando a decapitação se dá em um contexto ritualístico religioso e quando se trata de uma punição, de uma pena capital, inclusa aqui a possiblidade da prática de empalar os crânios para exibição pública, em alguns casos.

O contexto dos achados só faz aumentar a dificuldade em encontrar uma interpretação de consenso. Na maior parte dos casos em que se encontram corpos decapitados do período romano na ilha, as cabeças nem mesmo estão presentes, talvez usadas para algum tipo de ritual, ou para exposição pública, no caso de execuções, por exemplo. De fato, análises mais cuidadosas favorecem a tese de execução em massa em Driffield Terrace, em especial após a descoberta de dois corpos masculinos enterrados em duas camadas sobrepostas, sendo 
que um deles possuía grilhōes de ferro nas canelas. Outro fato marcante neste caso é que seus crânios haviam sido trocados (OTTAWAY, 2013, p. 225)! Curiosamente, se de fato os esqueletos são de vítimas de execuções de alguma natureza, a região de Driffield Terrace parece ter recebido os corpos destas vítimas até meados do séc. III d.C., como demonstrado pelo caso de outros vinte e tantos corpos decapitados em valas comuns nas proximidades, com o complicador de terem sido enterrados, por vezes, com cavalos. Marcas de corte nos ossos de alguns cavalos parecem indicar que tenham sido preparados para algum tipo de banquete ritualístico, algo tido como bastante incomum na Britannia. O cavalo, contudo, estava associado à deusa Epona, seu culto da Gália talvez introduzido na Britannia pela cavalaria romana, e a imagem equina teria um grande significado totêmico (OTTAWAY, 2013, p. 287).

Ao que se pode aferir, a partir das fontes clássicas, era comum a prática de decepar e cultuar a cabeça dos mortos em rituais religiosos da Gália da Idade do Ferro, talvez druídicos (SALWAY, 1984, p. 681). Conquanto o estudioso da religiāo bretã, Martin Henig (1984), hesite em afirmar categoricamente que os celtas sacrificavam humanos, admite que teria existido um culto das cabeças decepadas, tratadas de forma cerimonial, pois poderiam guardar a vida do guerreiro morto em batalha. O herói galês Bran teria pedido que lhe cortassem a cabeça, e esta continuou sendo usada para prever o futuro (HENIG, 1984, p. 18). O culto das cabeças não era apenas uma prerrogativa celta, todavia, e os romanos e gregos cultuavam a cabeça a sua maneira (HENIG, 1984, p. 19).

$\mathrm{Na}$ Bretanha, há indícios materiais do culto: uma moeda do rei bretão Cunobelino, onde se vê um sacerdote com uma cabeça nas mãos (SALWAY, 1984, p. 681). Há, também, esculturas de cabeças decepadas em Towcester e em Gloucester (essa última pode ser medieval, contudo) (TOYNBEE, 1971, p. 148; SALWAY, 1984, p. 692). Seriam mesmo cabeças cortadas após a morte, ou teriam sido a causa dela? Tácito (Ann. I, 61) fala dos crânios dos romanos vencidos pelos Germanos na derrota de Quintilo Varo, em 9 d.C., pregados aos troncos de árvores, mas também dos altares de sacrifício, locais onde teriam se dado as decapitações. As fontes clássicas fazem silêncio sobre exemplos na Britannia, o que poderia, num primeiro momento, indicar a ausência da prática. Contudo, cada vez 
mais surgem indicações do contrário sobre isso na Britannia (contra SALWAY, 1984, p. 692).

No poço da deusa Coventina, em Carrawburgh, no Muro de Adriano, foram encontrados mais de treze mil objetos votivos, inclusive um crânio. Os depósitos podem ter seguido até a época de expansão do cristianismo pela ilha. Segundo Peter Salway (1984, p. 691), no entanto, o crânio de Coventina pode ter sido um "acidente". Os chamados crânios da "camada de Boudica", de Walbrook, em Londres, podem indicar que os bretōes ainda caçavam cabeças, mas, para Salway, mostrar crânios de prisioneiros é comum até mesmo no mundo moderno e poderia não haver aqui nenhum motivo religioso específico (SALWAY, 1984, p. 691). Contudo, separar a religião das práticas mortuárias como um todo na Britannia é algo não recomendável, como mostram alguns estudos (ver TOYNBEE, 1971; e REECE, 1977, apud SALWAY, 1984, p. 693). Voltaremos aos crânios de Walbrook, Londres, mais adiante.

Os sepultamentos de Guilden Morden, em Cambridgeshire, e em Dorset apresentam três e quatro esqueletos decapitados, respectivamente. Entre estes, apenas um, o de um homem, tinha a cabeça cortada, mas deixada junto ao pescoço, enquanto os outros esqueletos, femininos, tinham suas cabeças entre os pés ou entre os joelhos (CHAMBERS, 1977; SALWAY, 1984, p. 706). Acredita-se que o homem tenha sido executado por algum crime, enquanto os corpos das mulheres teriam passado por algum ritual religioso de sepultamento.

Por vezes, como em Dunstable, os corpos mostravam posiçôes ainda mais inusitadas, as cabeças cortadas e depositadas perto das pernas, que cortadas também no joelho, tinham os pés, cercados de pregos de sapatos, voltados para o lado do pescoço. Neste caso, por ser de período tardio, séc. III d.C (SALWAY, 1984, p. 706), pode-se questionar se estamos diante da sobrevivência de um culto da Idade do Ferro ou diante de uma "inovação". Há também corpos decapitados no cemitério tardio de Lankhills, em Winchester, assim como os há no cemitério cristão saxão do sec. VII d.C., de Winnall, bem próximo. Não se sabe até o momento o que o culto da cabeça decepada poderia significar nestes contextos temporais distintos (HENIG, 1984, p. 225). ${ }^{4}$ Não parecem ter sido vítimas de execução, contudo.
4. Ver ainda: CLARKE, 1979, p. 372-5;

MacDONALD, 1979, p. 414-21; MEANEY \& HAWKES, 1970, p. 30-2. 
5. Sobre a possiblidade de nunca ter existido uma porta decumana, ver Gascoyne 2013, p. 75.
Em uma necrópole, próxima a Colchester (antiga $\mathrm{Ca}$ mulodunum, mais tarde, após a derrota de Boudica, nomeada Colonia Vitricensis), em uma escavação realizada nos anos de 1930, em Cedars Road, a leste do cemitério Butt Road, foram encontrados quatro corpos decapitados e desmembrados, com as cabeças posicionadas em seus colos (RADFORD, 2013c, p. 156). Mais uma vez, aqui, não se pressupõe a execução penal de nenhum dos indivíduos.

Já em um contexto militar do início do período de dominação romana sobre os nativos, vários sepultamentos foram achados, ainda, em Colchester, nas escavações de Balkerne Lane, onde seis corpos foram achados perto de um fosso da fortaleza dos legionários. Dois crânios e alguns ossos mostram sinais de violência, sendo que ao menos um deles parece ter sido executado, por decapitação. Podem ter sido corpos deixamos na porta decumana, uma passagem de soldados para execuções e punições (JOHNSON, 1983, p. 41; GASCOYNE, 2013, p. 73). ${ }^{5}$ Não se pode assegurar se são os corpos de soldados romanos ou de bretóes, punidos, em qualquer um dos casos, se confirmada a execução marcial. O que reina é a incerteza. O arqueólogo David Radford (2013b, p. 96), por sua vez, indaga se teriam sido os corpos executados em Balkerne Lane, possíveis vítimas de Boudica. O especialista em arqueologia de Colchester, Paul Sealey (2004, p. 19), acredita que tenham sido vítimas dos romanos, suas cabeças teriam sido empaladas, postas em postes para sua exibição pública, mas antes de 55 d.C., não estando, portanto, envolvidas com a revolta de Boudica (60 ou 61 d.C.).

Geralmente, tendo em mente a ojeriza dos romanos pela presença de mortos no interior das suas cidades, quando são achados corpos no interior destas, pode-se pensar, prima facie, em desconhecimento da existência dos mesmos ou assassinato e ocultação do cadáver. Seria esse o caso dos esqueletos desmembrados da Idade do Ferro tardia ou do início do período romano em fossos de Canterbury. Também em Canterbury, dois soldados enterrados parecem ter sido assassinados, seus corpos ocultados. Caso similar de um casal em Housesteads, cujo esqueleto masculino apresentava uma ponta de espada no espaço da cavidade torácica (SALWAY, 1984, p. 696).

Em uma perspectiva um pouco diferente para explicar os sepultamentos dentro das cidades, em Colchester (Camu- 
lodunum), foram escavados os corpos de um homem adulto, acompanhado de uma criança, perto do portão leste, datados de algo entre 132-533 d.C.. Foram ambos cuidadosamente decapitados após a morte, tendo suas cabeças depositadas entre os seus joelhos. A presença destes e de outros enterramentos pode demonstrar, talvez, o colapso das restrições contra enterramentos intramuros em um momento tardio (RADFORD, 2013c, p. 159-60). Já em um "sepultamento" mais paratático, um crânio achado na rua St. John, ainda na mesma cidade, apresenta fratura cranial não cicatrizada. Seria de um corpo decapitado, encontrado em um depósito de entulho, e pode ser do séc. I ou até do III d.C.. Outros enterramentos decapitados intramuros em Colchester podem representar indivíduos de baixa renda ou condenados ou algo do que ainda não se deu conta (RADFORD, 2013c, p. 160).

\section{OS CORPOS DE MASSACRES E A MÍDIA}

Em algumas ocasiões, os arqueólogos se deparam com uma grande quantidade de corpos depositados em poços, fossos, lagos, rios, ou em situação de aparente descuido funerário, como no exemplo de Driffield Terrace, onde corpos foram inumados sem caixões. Esses casos são costumeiramente tratados como indícios de "massacres". No caso da Britannia, os momentos de maior convulsão social são quase que imediatamente associados aos achados. Dentre tais momentos, o da Revolta de Boudica em 60/61 d.C, contra os romanos é o mais lembrado (SEALEY, 2004). No percurso de sua marcha, os revoltosos teriam destruído três localidades romanas na ilha: Colchester (Camulodunum), Londres (Londinium) e St Albans (Verulamium). Uma vez que os autores antigos nos relatam a crueldade empregada pelos nativos contra os romanos, e, mais tarde, quando de sua derrota para Suetônio Paulino, em local desconhecido, da revanche não menos sangrenta do governador sobre os vencidos, há um grande interesse em encontrar os vestígios humanos de tamanho embate.

$\mathrm{O}$ ataque de Suetônio Paulino contra os habitantes de Anglesey (Mona, para os romanos), no País de Gales, e a subsequente execução daquelas pessoas e dos druidas envolvidos (Tácito. Ann, XIV, 30; Díon Cássio. Hist. LXII, 1-11) ficou conhecido como o Massacre de Menai, nome do estreito que 
6. O incidente foi tema de uma reportage no site British History Net: http://british-history.net/ roman-britain/the-menaimassacre-and-boudica52-59-a-d/. Acessado em 06/02/2014.

7. Disponível em: http:// www.independent.co.uk/ news/science/archaeology/ exclusive-slaughteredbodies-stripped-of-theirflesh--a-gruesome-glimpseof-ironage-massacre-at-ukslargest-hill-fort-8798680. html . Acessado em 06/02/2014. separa Anglesey do resto da ilha. ${ }^{6} \mathrm{O}$ interesse da mídia em relatar e difundir tais descobertas se abre como um novo campo de estudo para os próprios pesquisadores, que podem se interessar por estudar o impacto causado pelo conhecimento de aspectos da violência ou de práticas mortuárias distintas de nosso tempo.

De grande impacto midiático, também, foi a descoberta do Massacre de Somerset (Yeovil), local do maior oppidum (bill fort) da Idade do Ferro na Bretanha: Ham Hill. O jornal britânico The Independent publicou em seu site de notícias $^{7}$, no dia 4 de setembro de 2013, uma reportagem sobre a descoberta de dezenas de corpos, datados dos séc. I d.C., em período romano, cujos ossos mostravam cortes estratégicos indicativos de remoção da carne a partir de juntas do corpo humano. A "escarnação" pode ter sido feita pelos nativos, em uma associação com o culto das cabeças decepadas, por exemplo, embora as mortes em si sejam atribuídas a algum tipo de execução em massa feita pelos romanos contra os bretôes da região da fortaleza. Ao menos, assim interpreta o arqueólogo responsável pela escavação, Marcus Brittain, da Universidade de Cambridge.

O caso dos mais de cem crânios de Walbrook, em Londres, é também significativo no contexto de massacres. Os restos humanos, na maioria crânios, encontrados acumulados no leito do antigo riacho, Walbrook, na área que teria sido central na antiga cidade romana de Londinium, estariam associados à revolta de Boudica. Pertenciam a adultos, na maioria dos casos, homens de meia idade. É comum associar esses crânios a possíveis vítimas de Boudica. Contudo, Tácito (Ann. XIV, 32-3) nos diz que os mais jovens e capazes teriam fugido de Londinium antes do ataque, ficando para trás apenas os velhos e incapacitados. A idade dos indivíduos não combina com o relato clássico (HENIG, 1984, p. 207). Seja como for, teriam sido vítimas da vingança de Suetônio Paulino? Os crânios estavam sem as mandíbulas, o que parece indicar que as cabeças foram lá depositadas depois de "escarnadas" (SEALEY, 2004, p. 34), aproximando os depósitos muito mais ao culto das cabeças decepadas do que às possíveis execuções romanas. Com o que sabemos das práticas religiosas dos bretóes e dos locais favorecidos para as deposiçóes de corpos, a presença de água nesse contexto não pode nos passar despercebida. Há ainda, 
a possibilidade tafonômica de os corpos pertencerem a uma necrópole localizada a montante, inundada pelas águas do Walbrook, quando então os crânios e outras partes dos corpos teriam sido deslocados corrente abaixo. ${ }^{8}$

Uma nova interpretação para os crânios do Walbrook seria o da presença de caçadores de cabeças, pessoa que se dedicariam a recolher as cabeças de executados para depositá-las em locais tidos como sagrados. O cenário é de incerteza. Mais uma vez um grande mistério ainda cerca tais práticas e os motivos para as deposiçôes dos corpos decapitados nessa região do Império ao longo dos séculos, desde a Idade do Ferro.

\section{ConClusāo}

Como alertamos ao início, qualquer estudo a respeito das representaçôes da morte na Bretanha, e na Britannia, deve levar em consideração as influências recebidas do continente. Ao mesmo tempo, ressaltamos que seria muito produtivo reconhecermos que os bretóes tiveram também suas próprias formas de representar a morte por meio das práticas mortuárias locais. Esperamos ter oferecido aqui uma oportunidade para vislumbrarmos os inúmeros desafios interpretativos que se abrem aos estudiosos do passado, em especial, da Bretanha, da Idade do Ferro à Britannia romana.

O papel da água no imaginário religioso bretão pode ter influenciado sobremaneira aquela sociedade, e pode, ainda, estar associado ao "culto da cabeça decepadas", na medida que muitas delas estão também em zonas úmidas. Os temores e anseios dos bretōes podem, talvez, ser reconhecidos em tais práticas, que ainda se mostram tão opacas a nós hoje. Suas representaçōes teriam durado séculos, sem que isso signifique ficarem estáticas, livres das impressōes de seus contextos históricos. É comum imaginarmos que as práticas mortuárias são estanques, um engano a ser evitado.?

Em um exemplo de possível transculturação, que apresenta longa tradição mesclada a novas percepçôes, teriam os bretōes, nos cemitérios de Dunstable e Lankhills, influenciados pelos valores místicos externos introduzidos pelo Império, cortado as cabeças de alguns de seus mortos para que não retornassem como fantasmas, tão temidos pelos romanos, como especula o especialista em religião Martin Henig (1984,
8. Ver a noticia: http:// walbrookdiscovery. wordpress. com/2012/10/05/a-waterygrave-the-walbrook-craniaa-taphonomic-explanation/. Acessado em 05/03/2014.

9. Ver debate pormenorizado em Ribeiro, 2007: 144 
p. 203)? As questôes estão em aberto, mas apontam para a importância de compreendermos melhor as sociedades antigas em suas complexas articulações e negociações culturais, religiosas, sociais e políticas. Faz-se importante, ainda, compreender os vestígios mortuários a partir da lógica da organização da sociedade, visto que há um enlace entre o mundo dos vivos e dos mortos (RIBEIRO, 2007, p. 153). Assim, o estudo das representaçôes dos mortos pode entrever outros campos de estudo, não comumente contemplados pela História e a Arqueologia ao estudarem as práticas mortuárias no passado, como o dos gêneros, da sexualidade, da violência e do poder, por exemplo.

O acesso do público não acadêmico ao tema, também é alvissareiro. Qual o papel da mídia na difusão desse conhecimento? Com notável frequência surgem notícias sobre novas descobertas arqueológicas de restos mortais humanos do período de presença romana nas ilhas britânicas. A maioria de tais achados está concentrada nos sites noticiosos britânicos, é verdade, mas não parece ser muito arriscado sugerir que há um amplo fascínio no mundo, ao menos o ocidental, pelo tema da morte nos tempos da Roma antiga. Se isso já não for tido como uma curiosidade lúgubre demais, saber, vez ou outra, que alguns dos corpos de pessoas daquela longínqua época permitem desvelar sinais de sevícias, nem sempre cria algum esperado (ou desejado) sentimento de repulsa ao tema da morte violenta. Ler a respeito da morte, natural ou violenta, e de elementos ritualísticos e funerários dos habitantes de uma província romana tão distante do Mediterrâneo pode se tornar uma atividade ainda mais fascinante quando as imagens das descobertas arqueológicas nos oferecem esqueletos, crânios (alguns decapitados, como vimos), com alguma sorte, corpos com tecidos moles preservados, caso dos bog bodies, e ainda, algumas reconstruçôes faciais. Esse interesse pode ser capitalizado para difundir um passado múltiplo e distinto de nosso tempo, evitando o sensacionalismo estéril. Os estudiosos do passado podem em muito contribuir ao trabalhar in tandem com os veículos midiáticos na divulgação dos resultados. O tema da religião e da violência, por si só, merece nossa atenção, e as representações da morte entre os bretôes parecem condutivas aos mais variados e promissores debates. 


\section{A) Documentação Textual:}

DÍON CÁSSIO. Epitome. http://penelope.uchicago.edu/ Thayer/E/Roman/Texts/Cassius_Dio/home.html

ESTRABÃO. The Geography of Strabo. Cambridge, Massachusetts: Harvard University Press, 1988.

JÚLIO CÉSAR. The Conquest of Gaul. Londres: Penguin Books, 1982.

OVÍDIO, Fasti. http://www.thelatinlibrary.com/ovid.html

PLÍNIO, o JOVEM. Epistolas. http://www.thelatinlibrary. com/pliny.html

PLÍNIO, o VELHO, História Natural. http://penelope.uchicago.edu/Thayer/E/Roman/Texts/Pliny_the_Elder/home. html

POLÍBIO. Histórias. http://www.perseus.tufts.edu/hopper/ text?doc $=\mathrm{Plb} .+$ toc\&redirect $=$ true

TÁCITO. Agrícola. http://www.forumromanum.org/literature/tacitus/agricola.html Brittanica, 1977.

. The Annals and the Histories. Encyclopaedia

Germania. http://www.perseus.tufts.edu/hopper $/$ text $?$ doc $=$ Tac. + Ger. $+1 \&$ redirect $=$ true

VIRGÍlIO, Eneida. http://www.thelatinlibrary.com/verg. html

B) Obras Gerais:

ALCOCK, J. Classical religious belief and burial practice in Roman Britain. Arch. Journ. CXXXVII, 50-85, 1980.

CHAMBERS, R. A. Current Archaeology, 57. 319, 1977.

CLARKE, G.. The Roman Cemetery at Lankhills. Winchester Studies 3. Oxford, 1979.

COLLINGWOOD, R. G.; MYRES, R. P. The Roman Inscriptions of Britain I. Oxford: OUP, 1965.

CONNOLLY, R. C.. Lindow Man - a prehistoric bog corpse. Anthropology Today 1(5). 15-7, 1985. 
FUNARI, P. P. A.. Roma: Vida pública e vida privada. São Paulo: Editora Atual. 2a. Ed., 1994.

GASCOYNE, Adrian. The Roman Legionary Fortress, AD 43-49. In: GASCOYNE, Adrian; RADFORD, David (org.). Colchester, Fortress of the War God. An Archaeological Assessment. Oxford: Oxbow Books, 2013, p. 59-76.

GASCOYNE, Adrian; RADFORD, David (org.). Colchester, Fortress of the War God. An Archaeological Assessment. Oxford: Oxbow Books, 2013.

GLOB, P. V.. The Bog People: Iron-Age Man Preserved. Nova Iorque: New York Review of Books, 1965.

GREEN, M.. The Gods of the Celts. Gloucester, Gloucestershire: A. Sutton, 1986

HENIG, M.. Religion in Roman Britain. Londres: BT Batsford Ltd., 1984.

JOHNSON, A.. Roman Forts. Londres: A \& C Black, 1983. JOY, Jody. Lindow Man. Londres: The British Museum Press, 2009.

KELLY, Eamonn. An Archaeological Interpretation of Irish Iron Age Bog Bodies. In: RALPH, Sarah (ed.). The Archaeology of Violence. Interdisciplinary Approaches. IEMA Proceedings, vol. 2. Nova Iorque: State University of New York Press, 2013, p.232-40.

MacDONALD, M. J.. Religion. CLARKE, p. 404-33, 1979.

MEANEY, A. L.; HAWKES, S. C.. Two Anglo-Saxon Cemeteries at Winnall (Society for Medieval Archaeology, Monograph no. 4, Londres, 1970.

OTTAWAY, P.. Roman Yorkshire - People, Culture and Landscape. Middleton Rd, Pickering: Blackthorn Press, 2013.

PAIN, S.. The Head from Worsley Moss. New Scientist, no.2414, p. 48-9, de 23 de setembro de 2003.

RADFORD, David. Camulodunum in the late Iron Age, c. $50 \mathrm{BC}-\mathrm{AD}$ 43. In: GASCOYNE, Adrian; RADFORD, David (org.). Colchester, Fortress of the War God. An Archaeological Assessment. Oxford: Oxbow Books, 2013, p. 33-57.

RADFORD, DAVID. The Early Roman Colonia, AD 49-61. In: GASCOYNE, Adrian; RADFORD, David (org.). Colches- 
ter, Fortress of the War God. An Archaeological Assessment. Oxford: Oxbow Books, 2013, p. 77-98.

RADFORD, DAVID. The Later Roman Town, AD 61-410. In: GASCOYNE, Adrian; RADFORD, David (org.). Colchester, Fortress of the War God. An Archaeological Assessment. Oxford: Oxbow Books, 2013, p. 99-174.

REECE, R. (ed.). Burial in the Roman World. CBA Research Report 22, 1977.

RIBEIRO, Marily S.. Arqueologia das Práticas Mortuárias: uma abordagem historiográfica. São Paulo: Alameda, 2007.

SALWAY, P.. Roman Britain. Oxford: OUP, 1984.

SALWAY, P.. Roman Britain (c. 55 BC - c. 440). In: MORGAN, K. O. (ed.) The Oxford Illustrated History of Britain. Oxford: OUP, 1989, p. 1-51.

SEALEY, Paul R.. The Boudican Revolt against Rome. Princes Risborough: Shire Publications Ltd. 2a Ed., 2004.

TOYNBEE, J. M. C.. Death and burial in the Roman World. Ithaca, Nova Iorque: Cornell University Press, 1971.

Recebido em março de 2014. Aprovado em julho de 2014. 
